\title{
Comparative Study between Oral Zinc Sulphate, Amino Acids Chelated Zinc and Placebo in Treatment of Viral Warts Talal A. Abd El-Raheem ${ }^{1}$, Shaheera M. El Shafie ${ }^{2}$, Marwa A. Nassar ${ }^{1}$, Marwa H. Sayed ${ }^{1}$ \\ ${ }^{1}$ Department of Dermatology, STDs, and Andrology, ${ }^{2}$ Department of Clinical Pathology, Faculty of Medicine, Fayoum University
}

\begin{abstract}
Background: Warts are tumors or growths caused by infection with Human Papilloma virus (HPV). More than $100 \mathrm{HPV}$ subtypes are known. They are a common presenting disease in children and adolescents which spread by direct contact or autoinoculation. The aim of the Work: The aim of this work was to assess and compare the efficacy and safety of oral zinc sulphate and amino acids chelated zinc in treatment of viral warts. Patients and Methods: This cross sectional case control study included 60 patients with multiple viral warts who were collected from the Dermatology, STDs and Andrology outpatient clinic of Fayoum university hospital during the period from November 2014 to November 2015. The patients were 29 males and 31 females with ages ranging from 15 to 60 years. Results: There was statistically significant difference in degree of response in zinc and control groups as no patient in control group showed any response while in both zinc groups $27.5 \%$ of patients showed variable degrees of response. Also, there was no statistically significant difference in degree of response in both zinc groups. Conclusion: oral zinc in its both forms used in our study is safe but needs time to act and the response is not high, so it is not fit to be used as a monotherapy, but rather to be combined with other wart treatment modalities. Recommendations: More studies are needed to assess the therapeutic effect of zinc and its efficacy in combinations in warts treatment with higher doses and longer duration of treatment.
\end{abstract}

Keywords: zinc sulphate, amino acids chelated zinc, treatment, viral warts.

\section{INTRODUCTION}

Cutaneous warts are a common presenting complaint in children and adolescents. They are caused by human papilloma virus (HPV). The treatment of warts poses a therapeutic challenge for physicians. No single treatment has been proved effective at achieving complete remission in every patient. As a result, many different approaches to wart therapy exist ${ }^{(\mathbf{1})}$.

There are various types of viral warts including common warts, plantar warts, mosaic warts, plane or flat warts, periungual warts, filiform warts, oral warts and genital warts ${ }^{(2)}$.

Common therapeutic modalities for viral warts include cryotherapy, keratolytics, topical immunotherapy with contact sensitizer, oral cimetidine, antimitotic agents, carbon dioxide laser, electrosurgery, photodynamic therapy, intralesional injection of antigens and topical immune response modifiers ${ }^{(3)}$.

Zinc is an important element that is found in every cell in the body. More than 300 enzymes in the body need zinc in order to function properly. It was found that some patients with multiple warts had low serum zinc levels and that oral zinc supplements may help the body get rid of viral warts ${ }^{(4)}$.

Zinc has been previously used as an immunomodulator in a number of dermatological diseases such as erythema nodosum leprosum and dissecting cellulitis of scalp ${ }^{(5)}$. Oral zinc sulfate has been tried in viral warts with encouraging results ${ }^{(6)}$.

In zinc deficiency, the function of the macrophages and $\mathrm{T}$ cells is impaired with fifty percent reduction in leucocytes and $40-70 \%$ reduction in antibody-mediated and cell-mediated immunity ${ }^{(7)}$.

The aim of this work was to assess and compare the efficacy and safety of oral zinc sulphate and amino acids chelated zinc in treatment of viral warts.

\section{PATIENTS AND METHODS Patients:}

This study included 60 patients with multiple viral warts who were collected from the Dermatology, STDs and Andrology outpatient clinic of Fayoum University Hospital during the period from November 2014 to November 2015. The patients were 29 males and 31 females with age ranged from 15 to 60 years. These patients were divided into 3 groups:

Group 1: Included 20 patients who received oral zinc sulphate.

Group 2: Included 20 patients who received oral amino acids chelated zinc.

Group 3: Included 20 patients who received oral placebo.

Inclusion Criteria:

- Patients with multiple resistant viral warts. 
- Patients aged from 15 to 60 years.

\section{Exclusion Criteria:}

- Ages below 15 and above 60 years.

- Patients with genital warts.

- Patients with chronic systemic diseases e.g.: diabetes mellitus, chronic liver or renal disease.

- Immunosuppressed patients e.g. patients on chemotherapy, HIV positive patients, patients on long term steroid therapy.

- Pregnancy or lactation.

- History of previous oral treatment for 6 months before the study.

- Full history was taken including age, sex, occupation, duration of the warts, previous treatments received for the warts and family history of same disease.

- Full examination to determine type of warts, their sites, size, number and distribution.

- Blood samples were taken for evaluation of serum level of zinc before and after treatment with zinc.

- Photos were taken for patients before, during and after treatment.

- Patients were examined after every two weeks for signs and symptoms of regression of the warts.

- Patients were followed up for 6 months after treatment.

This study was conducted with approval of Ethical committee of Faculty of Medicine, Fayoum University. Written consents were taken from the subjects before being involved in the study. The study details were explained to them. History and Clinical Evaluation:

\section{METHODS}

The current study was a cross sectional case control study, in which patients were randomly divided into:

○ Group (1) included 20 patients who received oral zinc sulphate in a dose of 5 $\mathrm{mg} / \mathrm{kg} /$ day up to $600 \mathrm{mg} /$ day in three divided doses (Octozinc capsules®, 110 $\mathrm{mg}$ zinc sulphate heptahydrate equivalent to $25 \mathrm{mg}$ elemental zinc) for 6 weeks.

- Group (2) included 20 patients who received oral amino acids chelated zinc (Zinctron capsules ${ }^{\circledR}$, zinc amino acid chelate $110 \mathrm{mg}$ equivalent to elemental zinc $11 \mathrm{mg}$ ). All included patients took 3 capsules per day for 6 weeks.

- Group (3) included 20 patients who received oral placebo for 6 weeks, served as controls.

\section{Steps of measurement of serum zinc level:}

Serum zinc level was evaluated using atomic absorption method ${ }^{(8)}$.

. Blood samples $(2 \mathrm{~m} 1)$ were collected from all patient groups in sterilized tubes under complete aseptic condition. After centrifugation, the clear serum was separated and examined.

\section{Statistical Analysis}

- Data was collected and coded to facilitate data manipulation and double entered into Microsoft Access and data analysis was performed using SPSS software version 18 under windows 7.

- Simple descriptive analysis in the form of numbers and percentages for qualitative data, and arithmetic means as central tendency measurement, standard deviations as measure of dispersion for quantitative parametric data, and inferential statistic test:

- For quantitative parametric data, student t-Test, ANOVA test and Paired t-test were used.

- For quantitative non parametric data, kruskal wallis test and Mann-whitney test were used.

- For qualitative data, Chi square test was used.

- The level $\boldsymbol{P} \leq \mathbf{0 . 0 5}$ was considered the cut-off value for significance.

\section{RESULTS}

60 patients with multiple resistant viral warts were included in this study, females were 29 $(48.3 \%)$ patients and males were 31 (51.7\%) patients. The patients were divided into 3 equal groups; 20 each. Group (1) received oral zinc sulphate, group (2) received oral amino acid chelated zinc and group (3) received oral placebo.

\section{Gender:}

There is no statistically significant difference in sex in the three study groups with (pvalue $>0.05$ ) which indicates proper matching in sex between all groups (table 1). 
Table (1): Comparisons of gender in different study groups

\begin{tabular}{|c|c|c|c|c|c|}
\hline \multirow{3}{*}{ Sex } & \multicolumn{3}{|l|}{ Study groups } & \multirow{3}{*}{ p-value } & \multirow{3}{*}{ Sig. } \\
\hline & Zinc sulphate & $\begin{array}{l}\text { Amino acid } \\
\text { chelated zinc }\end{array}$ & Control & & \\
\hline & No. $(\%)$ & No. $(\%)$ & No. $(\%)$ & & \\
\hline Males & $6(30 \%)$ & $13(65 \%)$ & $10(50 \%)$ & \multirow{2}{*}{0.08} & \multirow{2}{*}{ NS } \\
\hline Females & $14(70 \%)$ & $7(35 \%)$ & $10(50 \%)$ & & \\
\hline
\end{tabular}

\section{Age, onset and number of warts:}

There is no statistically significant difference in age between the three study groups with (p-value $>0.05$ ) as shown in (table 2) which indicates proper matching in age between all groups but onset of disease and number of warts show statistically significant difference with (p-value $<0.05$ ) with longer duration and higher number of warts in group (1) as shown in (table 2).

Table (2): Comparisons of age, onset and number of warts in different study groups

\begin{tabular}{|l|l|l|l|l|l|}
\hline \multirow{2}{*}{ Variables } & \multicolumn{3}{|c|}{ Study groups } & \multirow{3}{*}{ p-value } & \multirow{2}{*}{ Sig. } \\
\cline { 2 - 6 } & Zinc sulphate & $\begin{array}{l}\text { Amino acid } \\
\text { chelated zinc }\end{array}$ & Control & Mean \pm SD & \\
\cline { 2 - 6 } & Mean \pm SD & Mean \pm SD & $28.9 \pm 9.1$ & 0.7 & NS \\
\hline Age (year) & $27.9 \pm 11.4$ & $26.3 \pm 11.9$ & $4.9 \pm 2.4$ & $\mathbf{0 . 0 1}$ & S \\
\hline Onset of disease (m) & $\mathbf{9 . 1} \pm \mathbf{4 . 8}$ & $7.9 \pm 5.4$ & $7.4 \pm 4.1$ & $\mathbf{0 . 0 4}$ & S \\
\hline Number of warts & $\mathbf{1 6 . 3} \pm \mathbf{1 5}$ & $14.6 \pm 13.3$ & \\
\hline
\end{tabular}

\section{Type and site of warts:}

There is no statistically significant difference in wart type and site between all groups with (p-value $>0.05$ ) as shown in (table 3 ).

Table (3): Comparisons of wart type and site in different study groups as follow:

\begin{tabular}{|c|c|c|c|c|c|}
\hline \multirow{3}{*}{ Variables } & \multicolumn{3}{|c|}{ Study groups } & \multirow{3}{*}{ p-value } & \multirow{3}{*}{ Sig. } \\
\hline & Zinc sulphate & $\begin{array}{c}\text { Amino acid } \\
\text { chelated zinc }\end{array}$ & Control & & \\
\hline & No. $(\%)$ & No. $(\%)$ & No. $(\%)$ & & \\
\hline \multicolumn{6}{|l|}{ Wart type } \\
\hline Common & $10(50 \%)$ & $7(35 \%)$ & $7(35 \%)$ & \multirow{5}{*}{0.2} & \multirow{5}{*}{ NS } \\
\hline Planter & $2(10 \%)$ & $7(35 \%)$ & $8(40 \%)$ & & \\
\hline Plane & $7(35 \%)$ & $5(25 \%)$ & $2(10 \%)$ & & \\
\hline Filiform & $0(0 \%)$ & $0(0 \%)$ & $2(10 \%)$ & & \\
\hline Periungual & $1(5 \%)$ & $1(5 \%)$ & $1(5 \%)$ & & \\
\hline \multicolumn{6}{|l|}{ Wart site } \\
\hline Face & $2(10 \%)$ & $4(20 \%)$ & $4(20 \%)$ & \multirow{5}{*}{0.7} & \multirow{5}{*}{ NS } \\
\hline Foot & $7(35 \%)$ & $9(45 \%)$ & $8(40 \%)$ & & \\
\hline Forearm & $1(5 \%)$ & $1(5 \%)$ & $0(0 \%)$ & & \\
\hline Hand & $10(50 \%)$ & $5(25 \%)$ & $8(40 \%)$ & & \\
\hline Foot/hand & $0(0 \%)$ & $1(5 \%)$ & $0(0 \%)$ & & \\
\hline
\end{tabular}

\section{Serum zinc level before and after treatment:}

There is statistically significant increase in serum zinc level after treatment in patients who received zinc treatment with (p-value $<0.05$ ) while in control group there is statistically significant decrease in serum zinc level after treatment with (p-value $<0.05)$ as shown in (table 4$)$.

Table (4): Comparisons of Serum zinc level in patients received zinc treatment and in control group 
Comparative Study between Oral Zinc Sulphate...

\begin{tabular}{|l|c|c|c|c|c|c|}
\hline \multirow{2}{*}{ Serum Zinc(Microgram/dl) } & \multicolumn{2}{|c|}{$\begin{array}{c}\text { Zinc group } \\
(\mathrm{n}=40)\end{array}$} & \multicolumn{2}{c|}{$\begin{array}{c}\text { Control } \\
(\mathrm{n}=20)\end{array}$} & \multirow{2}{*}{ p-value } & \multirow{2}{*}{ Sig. } \\
\cline { 2 - 5 } & Mean & SD & Mean & SD & & \\
\hline Before treatment & $\mathbf{4 0 . 7}$ & 8.5 & 50.8 & 7.8 & $<\mathbf{0 . 0 0 1}$ & HS \\
\hline After treatment & 58.4 & 16.6 & $\mathbf{3 3 . 5}$ & 5.9 & $<\mathbf{0 . 0 0 1}$ & HS \\
\hline
\end{tabular}

There is statistically significant difference between serum zinc level before and after receiving treatment between group of patients who received zinc treatment and control group with $(p$-value $<0.05)$ as shown in (table 5).

Table (5): Comparison of effect of zinc treatment on patients treated with zinc and control group

\begin{tabular}{|c|c|c|c|c|c|c|}
\hline \multirow[t]{2}{*}{ Serum Zinc groups } & \multicolumn{2}{|c|}{$\begin{array}{c}\text { Zinc group } \\
(\mathrm{n}=40)\end{array}$} & \multicolumn{2}{|c|}{$\begin{array}{c}\text { Control } \\
(\mathrm{n}=20)\end{array}$} & \multirow[t]{2}{*}{ p-value } & \multirow[t]{2}{*}{ Sig. } \\
\hline & No. & $\%$ & No. & $\%$ & & \\
\hline \multicolumn{7}{|l|}{ Before treatment } \\
\hline Low level $(<50)$ & 36 & $90 \%$ & 10 & $50 \%$ & \multirow{2}{*}{0.001} & \multirow{2}{*}{ HS } \\
\hline Normal level (50-120) & 4 & $10 \%$ & 10 & $50 \%$ & & \\
\hline \multicolumn{7}{|l|}{ After treatment } \\
\hline Low level $(<50)$ & 14 & $35 \%$ & 20 & $100 \%$ & \multirow{2}{*}{$<0.001$} & \multirow{2}{*}{ HS } \\
\hline Normal level (50-120) & 26 & $65 \%$ & $\mathbf{0}$ & $\mathbf{0 \%}$ & & \\
\hline
\end{tabular}

There is statistically significant increase in serum zinc level after treatment in group (1) and (2) while in group (3) serum zinc level showed statistically significant decrease after treatment with (p-value < 0.05) and there is no statistically significant difference in serum zinc level after treatment between both zinc groups with (p-value >0.05) as shown in (tables 6,7).

Table (6): Comparisons of serum zinc level before and after treatment in each study group.

\begin{tabular}{|l|c|c|c|c|c|c|}
\hline \multirow{2}{*}{ Group } & \multicolumn{4}{|c|}{ Serum Zinc level } & \multirow{2}{*}{ p-value } & \multirow{2}{*}{ Sig. } \\
\cline { 2 - 6 } & \multicolumn{3}{|c|}{ Before } & \multicolumn{2}{|c|}{ After } & \\
\cline { 2 - 7 } & Mean & SD & Mean & SD & & \\
\hline Zinc sulphate & 38.3 & 7.9 & $\mathbf{5 9 . 1}$ & 15.1 & $<\mathbf{0 . 0 0 1}$ & HS \\
\hline Amino acid chelated zinc & 43.1 & 8.6 & $\mathbf{5 7 . 7}$ & 18.3 & $\mathbf{0 . 0 0 1}$ & HS \\
\hline Control & 50.8 & 7.8 & $\mathbf{3 3 . 5}$ & 6 & $<\mathbf{0 . 0 0 1}$ & HS \\
\hline
\end{tabular}

Table (7): Comparisons of serum zinc level in both zinc groups.

\begin{tabular}{|l|c|c|c|c|c|c|}
\hline \multirow{2}{*}{ Serum Zinc level } & \multicolumn{2}{|c|}{$\begin{array}{c}\text { Zinc sulphate } \\
(\mathrm{n}=20)\end{array}$} & $\begin{array}{c}\text { Amino acid chelated } \\
\text { zinc } \\
(\mathrm{n}=20)\end{array}$ & \multirow{2}{*}{ p-value } & \multirow{2}{*}{ Sig. } \\
\cline { 2 - 6 } & Mean & SD & Mean & SD & & \\
\hline Before treatment & 38.3 & 7.9 & 43.1 & 8.6 & 0.08 & NS \\
\hline After treatment & 59.1 & 15.1 & 57.7 & 18.3 & 0.8 & NS \\
\hline
\end{tabular}

Clinical results

Degree of response:

There is statistically significant difference in degree of response in zinc and control groups with (p-value $<0.05)$ as shown in (table 8).

Table (8): Comparisons of degree of response in zinc and control groups.

\begin{tabular}{|c|c|c|c|c|c|c|}
\hline \multirow[t]{2}{*}{ Degree of response } & \multicolumn{2}{|c|}{$\begin{array}{c}\text { Zinc group } \\
(\mathrm{n}=40)\end{array}$} & \multicolumn{2}{|c|}{$\begin{array}{c}\text { Control } \\
(\mathrm{n}=20)\end{array}$} & \multirow[t]{2}{*}{ p-value } & \multirow[t]{2}{*}{ Sig. } \\
\hline & No. & $\%$ & No. & $\%$ & & \\
\hline No response & 29 & $72.5 \%$ & 20 & $100 \%$ & \multirow{3}{*}{0.03} & \multirow{3}{*}{$\mathbf{S}$} \\
\hline Partial & 7 & $17.5 \%$ & 0 & $0 \%$ & & \\
\hline Complete & 4 & $10 \%$ & 0 & $0 \%$ & & \\
\hline
\end{tabular}

There is no statistically significant difference in degree of response in both zinc groups with (p-value $>0.05$ ) as shown in (table 9). 
Talal Abd El-Raheem et al.

Table (9): Comparisons of degree of response in both zinc groups

\begin{tabular}{|c|l|l|l|l|l|l|}
\hline \multirow{2}{*}{ Degree of response } & \multicolumn{2}{|l|}{ Zinc sulphate } & \multicolumn{2}{l|}{$\begin{array}{l}\text { Amino acid chelated } \\
\text { zinc }\end{array}$} & \multirow{2}{*}{ p-value } & \multirow{2}{*}{ Sig. } \\
\cline { 2 - 5 } & No. & $\mathbf{\%}$ & No. & \% & & \multirow{2}{*}{ NS } \\
\hline No response & 15 & $75 \%$ & 14 & $70 \%$ & \\
\hline Partial & 3 & $15 \%$ & 4 & $20 \%$ & \multirow{2}{*}{0.9} & \\
\hline Complete & 2 & $10 \%$ & 2 & $10 \%$ & & \\
\hline
\end{tabular}

Relation of age, onset and number of warts to response:

There is no statistically significant difference in degree of response in relation to age, onset and number of warts in both zinc treated groups with (p-value $>0.05$ ) as shown in (table 10).

Table (10): Comparisons of age, onset and number of warts in different degrees of response.

\begin{tabular}{|c|c|c|c|c|c|}
\hline \multirow{3}{*}{ Variables } & \multicolumn{3}{|c|}{ Degree of response } & \multirow{3}{*}{ p-value } & \multirow{3}{*}{ Sig. } \\
\hline & $\begin{array}{c}\text { No response } \\
(n=29)\end{array}$ & $\begin{array}{c}\begin{array}{c}\text { Partial } \\
(n=7)\end{array} \\
\end{array}$ & $\begin{array}{c}\text { Complete } \\
(n=4)\end{array}$ & & \\
\hline & Mean \pm SD & Mean \pm SD & Mean \pm SD & & \\
\hline Age (year) & $26.8 \pm 11.5$ & $26.4 \pm 10.8$ & $30.3 \pm 15.9$ & 0.8 & NS \\
\hline Onset of disease (m) & $9.1 \pm 5.6$ & $6.4 \pm 2.6$ & $7.3 \pm 3.2$ & 0.4 & NS \\
\hline Number of warts & $16.03 \pm 15.8$ & $15.1 \pm 8.5$ & $12 \pm 8.9$ & 0.9 & NS \\
\hline
\end{tabular}

Relation of gender of patients to response:

There is no statistically significant difference in degree of response in relation to gender in both zinc treated groups with ( $\mathrm{p}$-value $>0.05$ ) as shown in (table 11).

Table (11): Comparisons of gender in different degrees of response.

\begin{tabular}{|c|c|c|c|c|c|}
\hline \multirow{3}{*}{ Variables } & \multicolumn{3}{|c|}{ Degree of response } & \multirow{3}{*}{ p-value } & \multirow{3}{*}{ Sig. } \\
\hline & $\begin{array}{c}\text { No response } \\
(\mathbf{n}=29)\end{array}$ & Partial $(n=7)$ & $\begin{array}{c}\text { Complete } \\
(n=4)\end{array}$ & & \\
\hline & No $(\%)$ & No $(\%)$ & No $(\%)$ & & \\
\hline Male & $11(37.9 \%)$ & $6(85.7 \%)$ & $2(50 \%)$ & \multirow{2}{*}{0.07} & \multirow{2}{*}{ NS } \\
\hline Female & $18(62.1 \%)$ & $1(14.3 \%)$ & $2(50 \%)$ & & \\
\hline
\end{tabular}

\section{Relation of wart type and site to response:}

There is no statistically significant difference in degree of response in relation to wart type and site in both zinc treated groups with ( $\mathrm{p}$-value $>0.05$ ) as shown in (table 12).

Table (12): Comparisons of wart type and site in different degrees of response.

\begin{tabular}{|c|c|c|c|c|c|}
\hline \multirow{3}{*}{ Variables } & \multicolumn{3}{|c|}{ Degree of response } & \multirow{3}{*}{ p-value } & \multirow{3}{*}{ Sig. } \\
\hline & $\begin{array}{c}\text { No response } \\
(n=29)\end{array}$ & Partial $(n=7)$ & $\begin{array}{c}\text { Complete } \\
(n=4)\end{array}$ & & \\
\hline & No $(\%)$ & No $(\%)$ & No $(\%)$ & & \\
\hline \multicolumn{6}{|l|}{ Wart type } \\
\hline Common & $14(48.3 \%)$ & $2(28.6 \%)$ & $1(25 \%)$ & \multirow{4}{*}{0.5} & \multirow{4}{*}{ NS } \\
\hline Planter & $6(20.7 \%)$ & $1(14.3 \%)$ & $2(50 \%)$ & & \\
\hline Plane & $7(24.1 \%)$ & $4(57.1 \%)$ & $1(25 \%)$ & & \\
\hline Periungual & $2(6.9 \%)$ & $0(0 \%)$ & $0(0 \%)$ & & \\
\hline \multicolumn{6}{|l|}{ Wart site } \\
\hline Face & $2(6.9 \%)$ & $3(42.9 \%)$ & $1(25 \%)$ & \multirow{5}{*}{0.2} & \multirow{5}{*}{ NS } \\
\hline Foot & $12(41.4 \%)$ & $1(14.3 \%)$ & $3(75 \%)$ & & \\
\hline Forearm & $1(3.4 \%)$ & $1(14.3 \%)$ & $0(0 \%)$ & & \\
\hline Hand & $12(44.8 \%)$ & $2(28.6 \%)$ & $0(0 \%)$ & & \\
\hline Foot/hand & $1(3.4 \%)$ & $0(0 \%)$ & $0(0 \%)$ & & \\
\hline
\end{tabular}

In our study, from the 40 patients in zinc treated group, 11 patients showed variable response to treatment as follow: $4 / 40(10 \%)$ showed complete response, $7 / 40(17.5 \%)$ showed partial response and 29/40 (72.5\%) 
showed no response after 6 weeks of zinc treatment. Responders were divided according to type of zinc used as follow, in group (1) treated with zinc sulphate 5 patients showed variable response to treatment as follow: 2/20 (10\%) showed complete response, 3/20 (15\%) showed partial response while in group (2) treated with amino acids chelated zinc 6 patients showed variable response to treatment as follow: $2 / 20(10 \%)$ showed complete response, 4/20 (20\%) showed partial response. Non responders were 15/20 (75\%) in group (1) and $14 / 20(70 \%)$ in group (2).

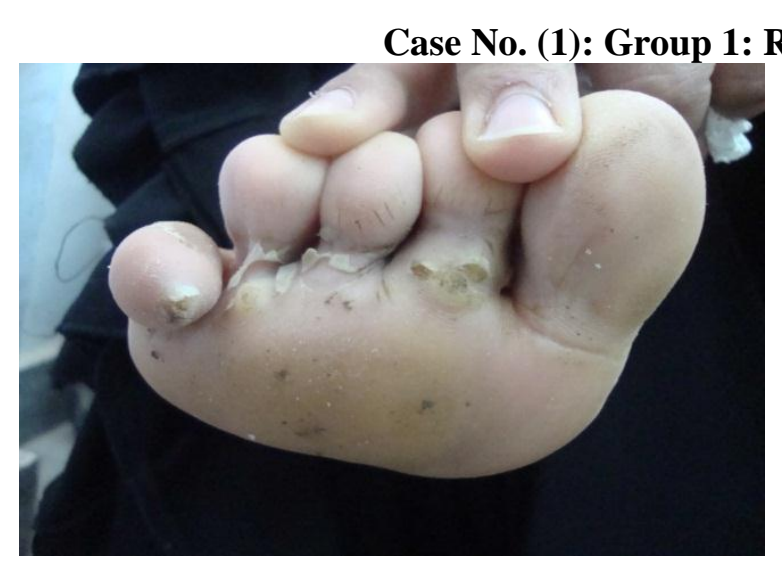

Figure (1): Before treatment

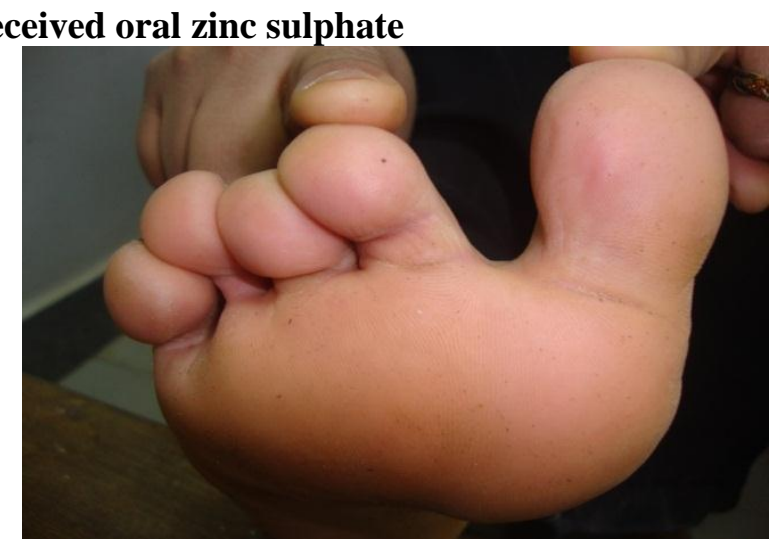

Figure (2): After treatment

Case No. (2): Group 2: Received oral amino acid chelated zinc

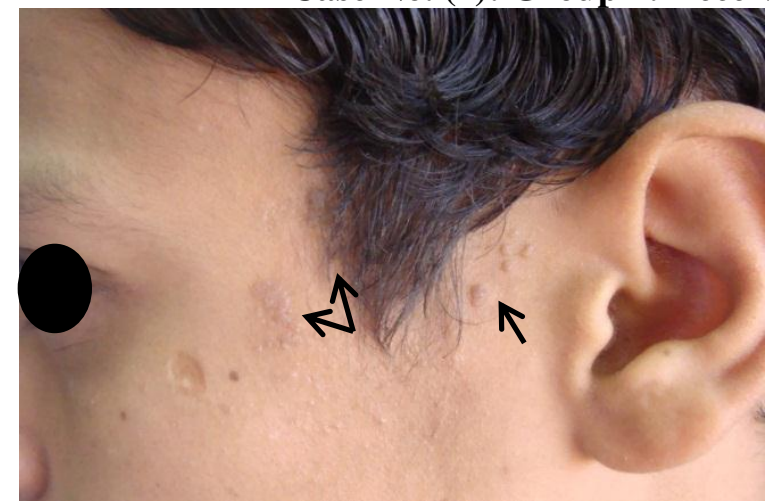

Figure (3): Before treatment

\section{DISCUSSION}

Treatment of warts is often challenging for both the physician and the patient. The treatment of patients with multiple, recalcitrant or recurrent verrucae continue to be a difficult task for both primary care physician and dermatologists ${ }^{(\mathbf{1})}$.

Multiple treatment modalities are available for treating warts but no treatment modality has succeeded in completely clearing warts and preventing recurrence in all patients. Most treatments directly destroy the visibly infected tissue, such as trichloroacetic acid, podophyllin, 5fluorouracil, cryosurgery, laser therapy, cauterization, and surgical excision. However, non-visible infected lesions are not targeted by these approaches ${ }^{(9)}$.

The importance of the immune system in the control of HPV infection and lesion development is shown by the fact that increased cellular immune responses correlate with a good clinical prognosis (10)

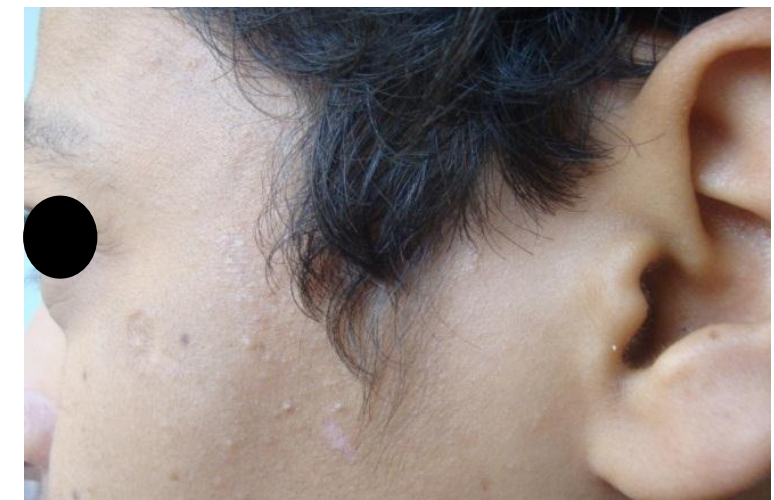

Figure (4): After treatment

Manipulating the immune system to achieve a therapeutic or protective response against diseases caused by HPV is an active field of investigation ${ }^{(11)}$.

Zinc is a cofactor of many metalloenzymes explaining that it plays an important role in cell proliferation and regulation of immune system, both the adaptive and innate immunity ${ }^{(\mathbf{1 2})}$.

A deficiency of zinc is said to have an adverse effect on cell mediated immunity. It appears that zinc may play a very important and critical role in the functions of human T-cells. Zinc is required for the biological activity of thymulin; which is a thymus specific hormone, which induces several $\mathrm{T}$-cell markers and promotes $\mathrm{T}$-cell functions ${ }^{(13)}$.

It has been suggested that zinc affects mainly the functions of Th1 cells. Even a mild deficiency of zinc in humans may be accompanied by an imbalance of Th1 and Th2 cells, decreased serum thymulin activity, decreased recruitment of $\mathrm{T}$ naive 
cells, a decreased percentage of $\mathrm{T}$ cytolytic cells, and decreased natural killer (NK) cell lytic activity (14).

Zinc is crucial to the normal development of immune cells, and it plays an important role in maintaining the activity of a range of immune cells, including neutrophils, monocytes, macrophages, NK cells, and B and T cells ${ }^{(\mathbf{1 5})}$.

Based on the above data, the current study tried to assess and compare the efficacy of oral zinc sulphate, amino acids chelated zinc and placebo in treatment of resistant viral warts.

Our study included 60 patients divided into 3 groups each of them included 20 patients. In this study oral zinc sulphate was given in a dose of 5 $\mathrm{mg} / \mathrm{kg} /$ day (max.600mg/day) for treatment of group (1), amino acids chelated zinc was given in a dose of $330 \mathrm{mg} /$ day for treatment of group (2) and placebo was given to group (3) all for 6 weeks for treatment of resistant viral warts. While studies by A1-Guairi et al. (4), Yaghoobi et al. ${ }^{(6)}$, LopezGarcia et al, ${ }^{(15)}$, Sadighha ${ }^{(16)}$, and Mun et al. ${ }^{(17)}$ used oral zinc sulphate in a dose of $10 \mathrm{mg} / \mathrm{kg} / \mathrm{day}$ (max. of $600 \mathrm{mg} /$ day) for 2 months for investigating its role in treatment of multiple viral warts. Hassan et al. ${ }^{(18)}$ worked on investigating the role of oral zinc sulphate in treatment of multiple viral warts, using oral zinc sulfate in a dose of $5 \mathrm{mg} / \mathrm{kg} /$ day (max. of $600 \mathrm{mg} /$ day) for 6 weeks.

In our study, controls included in group (3) are patients with multiple viral warts and this is similar to finding reported by Hassan et al. ${ }^{(18)}$. On another hand, in studies by A1-Gurairi et al. ${ }^{(4)}$, Yaghoobi et al. ${ }^{(6)}$, Sadighha ${ }^{(16)}$, Mun et al. ${ }^{(17)}$ and Lopez-Garcia et al. ${ }^{(14)}$ controls were healthy individuals which had higher baseline serum zinc level compared to baseline serum zinc level in patients with viral warts.

In our study the mean age of patients ranged from 27.9 \pm 11.4 years in group (1) and from $26.3 \pm 11.9$ in group (2) while in controls ranged

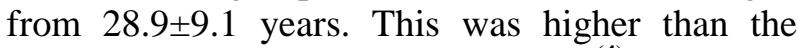
finding reported by Al-Gurairi et al. ${ }^{(4)}$, Sadighha ${ }^{(15)}$, Yaghoobi et al. ${ }^{(6)}$ and Mun et al. ${ }^{(16)}$ as the patient ages were 20,15.9 $\pm 4.87,17.6 \pm 5.44$ and 26 years respectively but lower than the age reported by Hassan et al. (18) which was $32.15 \pm 8.10$ in patient group and $30.28 \pm 7.15$ in control group.

In the present study, there was no statistical significant correlation between age and sex of the patients in different study groups and response to treatment. This is similar to the findings reported by Al-Gurairi et al, ${ }^{(4)}$. On the other hand Mun et al. (17) reported that younger patients responded better to treatment as $7 / 10(70 \%)$ of pediatric patients compared to $6 / 16(38 \%)$ in adult patients responded to treatment.

In our study, common warts were represented more followed by plantar, plane, filiform then periungual warts but no specific type, site or number of warts showed statistical significant correlation to response which is similar to the findings reported by Al-Gurairi et al. ${ }^{(4)}$

In our study, in zinc treated group 36/40 (90\%) patients had low baseline serum zinc level before treatment as it was $40.7 \pm 8.5 \mathrm{microgram} / \mathrm{dl}$ while in control group 10/20(50\%) patients had low baseline serum zinc level as it was $50.8 \pm 7.8$ microgram/dl while in Al-Gurairi et al. (4), Sadighha ${ }^{(16)}$ and Yaghoobi et al. ${ }^{(6)}$ the mean base line serum zinc levels in patients group were 62.5 $\pm 10.72,53.3 \pm 9.7$ and $55.09 \pm 10.07 \mathrm{microgram} / \mathrm{dl}$ respectively but in the controls the results were $66.4,58.04 \pm 9.13$ and $56.63 \pm 8.73$ respectively.

In contrast Lopez-Garcia et al. ${ }^{(15)}$ did not show low base line serum zinc level as it was 100.2 microgram/dl in patients group and 100.3 microgram/dl in controls.

In our study, from the 40 patients in zinc treated group, 11 patients showed variable response to treatment as follow: 4/40 (10\%) showed complete response, $7 / 40(17.5 \%)$ showed partial response and 29/40 (72.5\%) showed no response after 6 weeks of zinc treatment. Responders were divided according to type of zinc used as follow, in group (1) treated with zinc sulphate 5 patients showed variable response to treatment as follow: $2 / 20(10 \%)$ showed complete response, $3 / 20(15 \%)$ showed partial response while in group (2) treated with amino acids chelated zinc 6 patients showed variable response to treatment as follow: $2 / 20$ (10\%) showed complete response, 4/20 (20\%) showed partial response. Non responders were $15 / 20(75 \%)$ in group (1) and 14/20 (70\%) in group (2).

Our patient groups treated with zinc results were nearly similar to the findings of Lopez-Garcia et al. ${ }^{(14)}$ who reported that $4 / 25(16 \%)$ had complete resolution of warts and 3/25 (12\%) had only improved. In contrast our results in patients group were lower than the findings of Al-Gurairi et al. (4), Sadighha ${ }^{(16)}$, Yaghoobi et al. ${ }^{(6)}$, and Mun et al. ${ }^{(17)}$ who reported that 20/23 (86.9\%), 10/13 (76.9\%),25/32 (78.1\%) and 13/26 (50\%) respectively of patients group showed complete resolution of warts after 2 months of oral zinc sulphate also in Hassan et al. ${ }^{(18)}$ our results in patient groups treated with zinc were lower than the findings reported as 
25/41 (60.97\%) showed complete resolution of warts, $6 / 41(14.63 \%)$ showed partial response and 10/41 (24.39\%) showed no response after 6 weeks of oral zinc sulfate in dose of $5 \mathrm{mg} / \mathrm{kg} /$ day.

From the 20 patients in the control group in our study no patient showed any response after 6 weeks of placebo. These results go in accordance with the results reported by Al-Gurairi et al. ${ }^{(4)}$ and Mun et al. ${ }^{(17)}$.Our control group results were different from the findings of Sadighha (16), Yaghoobi et al. ${ }^{(6)}$ who reported that $1 / 13$ and 3/23 from controls showed improvement of warts. Also Lopez-Garcia et al. ${ }^{(15)}$ reported that $3 / 25$ of controls showed complete resolution of warts and another 3 showed improvement of warts. Also Hassan et al. ${ }^{(18)}$ reported that 2/31 (6.45\%) showed partial response.

The patients who responded completely to oral zinc treatment in its both forms used were regularly followed up for a period of six months with no evidence of recurrence of the warts.

On reviewing literature, we found that it is the first study to use oral amino acids chelated zinc in treatment of viral warts and comparing its efficacy with oral zinc sulphate. During this study, no side effects were detected except some gastric upset with few patients in group (1) that did not require stoppage of treatment.

The discrepancy between our results and the results of previous studies may be due to the longer duration of treatment or higher dose of zinc treatment.

\section{CONCLUSION}

- As zinc is required for the immune system to function efficiently, our findings suggest that zinc can play a role in wart treatment in some patients but still there are factors other than serum zinc that may also participate in immunity failure against clearance of viral warts.

- Our results showed that both oral zinc sulphate and amino acids chelated zinc had nearly the same effect on treatment of warts but in general, response rate is not high. This makes it inefficient as a monotherapy for warts but can be given as a complementary treatment with other treatment modalities and to prevent recurrences.

- After comparison between prices of oral zinc sulphate and amino acids chelated zinc we found that oral zinc sulphate is cheaper so it is preferred for better financial compliance of patients.

\section{RECOMMENDATIONS}

- Both oral zinc sulphate and amino acids chelated zinc had the same efficacy on warts but they are recommended as a complementary treatment modality of warts but not as monotherapy in treatment of multiple resistant warts.

- Because of the low price of oral zinc sulphate compared to that of oral amino acids chelated zinc, it is preferred for better financial compliance of patients.

- More studies are needed to assess the therapeutic effect of zinc in its both forms used in warts treatment with higher doses and longer duration of treatment.

- Further studies are needed to assess the efficacy of zinc in combinations with other immunotherapeutic agents or with other treatment modalities of warts to prevent recurrences.

\section{REFERENCES}

1. Bacelieri $R$ and Johnson SM (2005): Cutaneous warts: an evidence-based approach to therapy. Am. Fam. Physician, 72: 647-52.

2. Salk RS, Grogan KA and Chang TJ (2006): Topical 5\% 5-fluorouracil cream in the treatment of plantar warts: a prospective, randomized, and controlled clinical study. J Drugs Dermatol., 5:418-24.

3. Park HS and Choi WS (2008): Pulsed dye laser treatment for viral warts: A study of 120 patients. J Dermatol., 35:491-8.

4. Al-Gurairi FT, Al-Waiz M and Sharquie KE (2002): Oral zinc sulphate in the treatment of recalcitrant viral warts: Randomized placebo controlled trial. Br J Dermatol., 146:423-31.

5. Mahajan PM, Jadhar VH and Patki AH (1994): Oral zinc in recurrent erythema nodosum leprosum: a clinical study. Indian $\mathbf{J}$ Lepr., 66:51-7.

6. Yaghoobi R, Sadighha A and Baktash D (2009): Evaluations of oral zinc sulfate effect on recalcitrant multiple viral warts: a randomized placebo- controlled clinical trial. J Am Acad Dermatol., 60:706-8.

7. Haase $H$ and Rink $L$ (2009): The immune system and the impact of zinc during aging. Immune Ageing, 6:9-10.

8. Butrimovitz GP, Purdy WC (1977): The determination of zinc in blood plasma by atomic absorption spectrometry. Analytica chimica acta., 94(1):63-73.

9. Bohle A, Buttuer H, and Jocham D (2001): Primary treatment of condylomata acuminata with viable bacillus Calmette-Guerin. J Urol., 165: 834-36. 
10. Fausch SC, Da-Silva DM, Kast WM and Fahey LM (2005): HPV can escape immune recognition through Langerhans Cell Phosphoinositide 3-Kinase Activation. J Immunol., 174:7172-8.

11. Horn TD, Johnson SM, Helm RM and Roberson PK (2005): Intralesional immunotherapy of warts with mumps, candida and trichophyton skin test antigens. Arch Dermatol., 141:589-594.

12. Brocard A, Knol AC and Khammari A (2007): Hidradenitis suppurativa and zinc: A new threaputic approach: A pilot study. Dermatol, 214:325-7.

13. Prasad AS (2007): Zinc mechanisms of host defense. J Nutr., 137:13459.

14. Heyland DK, Jones N, Cvijanovich NZ and Wong H (2008): Zinc supplementation in critically ill patients. A key pharmaconutrient J Parenter Enteral Nutr., 32:509-19.

15. Lopez-García DR, Gómez-Flores M, ArceMendoza AY, De La Fuente-García A and
Ocampo-Candiani J (2009): Oral zinc sulfate for unresponsive cutaneous viral warts: too good to be true? A double-blind, randomized, placebo-controlled trial. Clinical Exp Dermatol., 34:984-985.

16. Sadighha A (2009): Oral zinc sulfate in recalcitrant multiple viral warts: A pilot study. J Eur Acad Dermatol Venerol., 23:715-54.

17. Mun JH, Kim SH, Jung DS, Ko HC, Kim BS, Kwonk KS and Kim MB (2011): Oral zinc sulfate treatment for viral warts: An open-label study. The Journal of Dermatology, 38:541-45.

18. Hassan I, Bhat T, Altaf H, Sameem F and Masood Q (2013): Role of oral zinc sulphate in warts-a placebo controlled, single-blinded study. Our Dermatol Online, 4:24-27. 